\title{
KONSEP PRAJURIT ALLAH BERDASARKAN EFESUS 6:10- 20 DAN IMPLEMENTASINYA DALAM KEHIDUPAN ORANG PERCAYA
}

\author{
Yolanda Olivya Kadjakoro \\ Mahasiswa STT Injili dan Kejuruan Kupang \\ squarepants_yolanda@yahoo.com
}

\begin{abstract}
A soldier of God will always be identical to his armor. God's armor itself is a picture used by the Apostle Paul in his letter to the congregation at Ephesus. Paul ended this letter to the congregation by giving a description of the weapons used by the Roman army at that time. The weapons themselves are belts, armor, shoes, shields, helmets and swords. Paul gives this picture so that his readers in Ephesus can understand that it is actually one of the Roman provinces. This weapon of God does not only apply to the Ephesians, but can also be drawn into the lives of believers, namely that the war of believers against the powers of Satan must be equipped with truth, justice, willingness, faith, the word of God, and prayer.
\end{abstract}

Key words: Ephesians 6:10-20, Believers, God's soldier

\begin{abstract}
Abstrak
Seorang prajurit Allah akan selalu identik dengan perlengkapan senjatanya. Perlengkapan senjata Allah sendiri merupakan suatu gambaran yang dipakai oleh Rasul Paulus dalam suratnya kepada jemaaat di Efesus. Paulus mengakhiri suratnya ini kepada jemaat disana dengan memberikan gambaran perlengkapan senjata yang dipakai oleh tentara Romawi pada saat itu. Perlengkapan senjata itu sendiri ialah ikat pinggang, baju zirah, kasut kaki, perisai, ketopong, dan pedang. Paulus memberikan gambaran ini agar dapat dimengerti oleh pembacanya di Efesus yang notabene adalah salah satu propinsi Romawi. Perlengkapan senjata Allah ini tidak hanya berlaku bagi jemaat di Efesus saja, tetapi juga dapat ditarik ke dalam kehidupan orang percaya yaitu bahwa peperangan orang percaya melawan kuasakuasa Iblis harus dilengkapi dengan kebenaran, keadilan, kerelaan, iman, firman Allah, dan doa.
\end{abstract}

Kata kunci: Efesus 6:10-20, orang percaya, prajurit Allah

\section{Pendahuluan}

Surat Efesus adalah salah satu surat yang dituliskan Paulus ketika ia berada di dalam penjara dan surat ini juga merupakan salah satu surat edaran kepada jemaat-jemaat di Asia. Paulus menulis surat ini untuk mendorong orang Kristen Yunani untuk menerima minoritas orang Yahudi dalam persekutuan gereja dan memelihara hubungan mereka dengan tradisitradisi Israel sehingga Paulus merasa bahwa ia perlu mengirimkan surat kepada jemaat di Efesus dan mencoba berbicara kepada mereka tentang keesaan gereja. Paulus tak ingin 
melihat adanya dua gereja: gereja Yahudi dan gereja bukan Yahudi, melainkan "satu gereja" yang kudus dan am; Yahudi dan bukan Yahudi bersatu dalam Kristus. ${ }^{1}$

Pasal 1 dalam surat ini berbicara tentang berkat-berkat rohani yang telah diterima oleh jemaat dalam Kristus. Lalu pasal 2 dan 3 berbicara tentang gereja menyatukan segala bangsa. Lalu pasal 4 mengenai keesaan gereja. Dan pasal 5, 6 tentang kewajiban baru. Secara khusus pasal 6:10-20 ini, Paulus menjelaskan tentang perlengkapan senjata Allah, bagaimana Paulus ingin jemaat Efesus memperlengkapi diri mereka sebelum "berperang". Rasul Paulus sebelum menutup suratnya dengan pemberitahuan dan salam, ia memberikan nasihat kepada jemaat di Efesus tentang perjuangan mereka. Nasihat Paulus ini bukan ditujukan karena jemaat yang masih baru dalam iman Kristen, tetapi kepada mereka yang telah mencapai kematangan tertentu dalam pengalaman rohani, dan ingin meningkat kepada pengetahuan dan kehidupan yang lebih penuh. ${ }^{2}$

Adapun masalah yang menyebabkan pasal 6 ini muncul, besar kemungkinan dikarenakan adanya aliran gnostik dan agama-agama misteri yang muncul pada saat itu. Aliran gnostik sendiri adalah aliran yang mencampurkan berbagai macam ajaran agama sehingga dikatakan bahwa aliran ini adalah aliran sesat. Gnostisime adalah kumpulan dari agama-agama kuno yang para pengikutnya menjauhkan diri dari dunia materi. ${ }^{3}$ Namun perlu diketahui bahwa sekte Gnostisisme sendiri muncul sebelum kelahiran Yesus yang berarti bahwa sebelum jemaat di Efesus ada, aliran ini telah muncul jauh terlebih dahulu. Adanya keinginan untuk melepaskan diri dari penjara tubuh untuk naik ke alam atas, kemudian perintah Paulus untuk menanggalkan sifat lama, dan mengenakan sifat baru (Ef. 4:22, 24) mengingatkan pada sikap oposisi terhadap pandangan gnostik. Misalnya, penyerahan diri kepada hawa nafsu, melakukan kecemaran adalah sesuai dengan kecenderungan gnostik. ${ }^{4}$

Disini dapat dilihat bahwa Paulus ingin mengingatkan jemaat di Efesus bahwa gereja sedang berjuang tetapi bukan berjuang melawan manusia melainkan "...melawan pemerintah-pemerintah, melawan penguasa-penguasa, melawan penghulu-penghulu dunia yang gelap ini, melawan roh-roh jahat di udara." (Ef 6:12). "So, the devil is back in business again." Kalimat ini menyiratkan bahwa kuasa kegelapan saat ini benar-benar ada dan sedang "beroposisi" dengan kuasa terang, yang bertujuan untuk membentuk opini dan mempengaruhi manusia - siapa yang lebih kuat dan berkuasa di antara keduanya. ${ }^{5}$ Dr. J. L. Ch. Abineno mengutip perkataan salah seorang penafsir dalam buku nya Tafsiran Alkitab Surat Efesus yang mengatakan bahwa gereja sedang berjuang tetapi bukan berjuang melawan manusia. Kalau ada manusia yang menentang, mereka hanya alat saja dalam tangan kuasa-kuasa yang lebih tinggi. Hal ini memang tidak mengurangi hebatnya perjuangan, tetapi situasinya toh menjadi lain. Gereja tidak berdiri sendiri; ia adalah alat dan anggota-anggotanya adalah hamba-hamba dari Tuhan dan Raja, yang memimpin perjuangan yang sebenarnya. Pada kedua pihak ada sesuatu, yang mempunyai hubungan dengan "kuasa-kuasa rohani". Disitu manusia hanya memainkan peranan sekunder. ${ }^{6}$ Ketika Paulus menulis tentang peperangan rohani di akhir surat ini, dia tidak mengganti topik

${ }^{1}$ Henry H. Halley, Penuntun ke Dalam Perjanjian - Baru (Surabaya: Yakin, t.t.), 230.

${ }^{2}$ Merrill C. Tenney, Survei Perjanjian Baru (Jawa Timur: Gandum Mas, t.t.), 394.

${ }^{3}$ Roby Setiawan, "Tanggapan Terhadap Bidat Gnosticisme dan Injil Tomas," Jurnal Simpson 2, no.1 (Juni 2015): 2.

4Samuel Benyamin Hakh, Perjanjian Baru: Sejarah, Pengantar, dan Pokok-pokok Teologisnya (Bandung: Bina Media Informasi, 2010), 229-230.

5 Ferry Y. Mamahit, "Christus Victor dan Kemenangan Orang Kristen Terhadap Kuasa Kegelapan," Jurnal Veritas 5, no.1 (April 2004): 1.

6J. L. Ch. Abineno, Tafsiran Alkitab: Surat Efesus (Jakarta: BPK, 2009), 235. 
tetapi merangkum apa yang telah dia katakan sebelumnya. Paulus sangat antusias agar kita menyadari bahwa kehidupan adalah peperangan, bukan dengan orang lain, melainkan dengan roh-roh jahat di udara. ${ }^{7}$

Perlengkapan prajurit Allah sendiri digambarkan dengan kelengkapan peralatan tentara Romawi agar jemaat di Efesus dapat memahami dengan mudah maksud Paulus. Besar kemungkinan juga Paulus memakai gambaran ini karena ia selama hidupnya sering berkomunikasi dengan tentara Romawi; karena ia sendiri adalah warga negara Romawi dan sangat patriotik. Dikatakan juga bahwa dia memiliki kekaguman tersendiri pada tentara Romawi. ${ }^{8}$ Kekaguman Paulus ini bisa saja karena orang Roma dalam peperangan, mereka dapat membangun balatentara rakyat yang sesungguhnya dan angkatan laut yang kuat. Orang Roma juga memiliki kemampuan untuk membangun dan mengorganisasi dan itulah yang menyebabkan runtuhnya hampir semua musuh mereka. ${ }^{9}$

Adapun frasa perlengkapan senjata Allah ini,dalam Alkitab Terjemahan Baru dikatakan "perlengkapan rohani", dalam New King James Version disebut "The Whole Armor of God", dan dalam New International Version digunakan "The Armor of God". Dan jika dilihat tidak banyak perbedaan yang signifikan mengenai perikop dari Efesus 6:10-20 ini.

Dalam Efesus 6:11a New Internasional Versionditulis, "Put on the whole armor of God...".

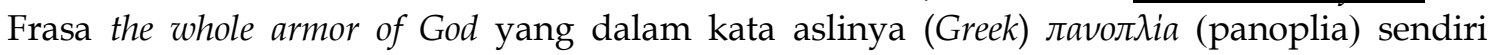
berarti "seluruh perlengkapan senjata"10. Kata ini berasal dari kata $\pi \dot{\varsigma}$ (pas) yang berarti "setiap" dan ó $\pi$ रov (oplon) yang berarti "alat yang dipakai dalam perang". Dan kata ini hanya dipakai 3x dalam Perjanjian Baru yaitu dalam Lukas 11:22; Efesus 6:11, 13. Lukas 11:22 bermakna persediaan Allahsedangkan Efesus 6:11, 13 mempunyai arti bahwa bantuan rohani dibutuhkan untuk melawan godaan Iblis. Dalam tafsiran kata asli, $\pi \alpha v o \pi \lambda i \alpha t i d a k$ diragukan lagi tentang aplikasi yang terlepas dari penggunaannya; kata лалолגia bisa berarti perlengkapan senjata, lengkap atau tidak. Tetapi kalimat "seluruh perlengkapan senjata Allah" memiliki makna yang tepat sekali disini, dimana titik poin kalimat ini ialah berarti ada satu rahasia yaitu kekuatan rohani; kebutuhan perlindungan ilahi dan digunakan untuk seluruh keadaan darurat. ${ }^{11}$

Telah diketahui bahwa masalah yang terjadi dalam jemaat di Efesus ini bukan karena jemaat yang baru mengenal akan Kristus tetapi mereka sudah berada dalam tahap pendewasaan sebagai jemaat. Paulus ingin mendorong jemaat di Efesus agar lebih dewasa lagi dalam iman mereka. Setelah Paulus menguraikan beberapa kebenaran dalam pasalpasal sebelumnya dalam surat Efesus, pada pasal-pasal terakhir ini Paulus ingin menjelaskan tujuannya yaitu bahwa ia berharap jemaat dapat berjalan sesuai dengan panggilan surgawi (Efesus 4:1). Dan Paulus mengharapkan bahwa kebenaran yang telah ia sampaikan kepada jemaat dapat dipraktekkan dalam kehidupan mereka baik di dalam gereja, rumah, maupun di dunia.

Perlengkapan senjata Allah yang digambarkan Paulus ini tidak hanya berlaku bagi jemaat di Efesus saja pada waktu itu tetapi juga berlaku dalam kehidupan orang percaya masa kini. Orang percaya saat ini terlibat dalam suatu peperangan rohani dalam hal melawan kejahatan. Perang ini akan terus berlangsung sampai orang percaya memasuki

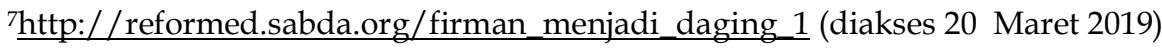

8https:/ / dandelionsalad.wordpress.com/2007/09/02/the-armor-of-god-an-exposition-ofephesians-610-17-by-warren-doud/ (diakses 18 Maret 2019)

9J.I. Packer, Merrill C. Tenney, William White Jr., Ensiklopedi Fakta Alkitab: Bible Almanac 1 (Jawa Timur: Gandum Mas, 2003), 636.

${ }^{10}$ Blue Letter Bible, http://www.blbclassic.org/lang/lexicon/Lexicon.cfm?strongs=G3833 (diakses 15 Maret 2019).

11https:// biblehub.com/commentaries/ephesians/6-11.htm (diakses 18 Maret 2019) 
hidup yang kekal (2 Tim 4:7-8). ${ }^{12}$ Orang percaya yang saling bersekutu di dalam gereja harus mempercayai bahwa penggerak kehidupan gereja adalah Roh Kudus, yang merupakan meterai penerimaan (Efesus 1:13).13

Pengertian dasar peperangan itu ialah bahwa hidup orang percaya berada di antara dua kekuatan yang saling bertentangan yaitu kekuatan Allah dan kekuatan Iblis. Namun tetap harus diketahui bahwa kekuatan Allah lah yang tertinggi dari semuanya. Orang percaya terpanggil untuk menggabungkan diri pada pihak Allah dan melawan musuh-Nya dengan menggunakan alat perang yang dikenakan sendiri oleh Allah (Yesaya 59:17).14 Warren Wiersbe dalam tafsirannya mengatakan, "Sebagai orang-orang Kristen, kita menghadapi tiga musuh yaitu: dunia, daging, dan Iblis (Efesus 2:1-3). "Dunia" mengacu pada sistem di sekitar kita yang menentang Allah, "daging" adalah sifat lama yang kita warisi dari Adam, suatu sifat yang menentang Tuhan dan sifat itu tidak dapat melakukan apapun secara rohani untuk menyenangkan Tuhan. Tetapi melalui kematian dan kebangkitan Yesus, Dia mengalahkan dunia (Yohanes 16:33; Galatia 6:14), daging (Roma 6:16; Galatia 2:20), dan Iblis (Efesus 1:19-23). Dengan kata lain, sebagai orang percaya, kita tidak berjuang untuk kemenangan tetapi kita berjuang karena kemenangan! Dan hanya Roh Allah yang memampukan kita, melalui iman, untuk memiliki kemenangan Kristus bagi diri kita." 15

\section{Metode}

Dalam penelitian ini penulis menggunakan metode kualitatif. Metode penelitian kualitatif merupakan penelitian yang bersifat deskripsi, cenderung menggunakan analisis dan lebih menonjolkan proses makna. Penulis menggunakan metode kualitatif dikarenakan adanya penyelidikan menggunakan tafsiran-tafsiran sehingga penggunaan angka-angka tidak terpakai dalam penulisan ini. Dalam pembahasan ini, penulis melakukan penelitian dengan melakukan eksegesis mengenai konsep prajurit Allah berdasarkan surat Efesus 6:1020. Menurut Gordon D. Fee dan Douglas Stuart, eksegesis adalah hal mempelajari dan membahas Alkitab secara sistematis dan teliti untuk menemukan arti asli yang dimaksudkan. ${ }^{16}$ Sesuai dengan pengertian tersebut, maka penulis akan melakukan analisa dan penelitian terhadap teks Efesus 6:10-20. Adapun teknik pengumpulan data yang digunakan adalah dengan melakukan penelitian kepustakaan (Library Research), terhadap berbagai sumber data antara lain: Alkitab, tafsiran-tafsiran, ensiklopedi dan buku-buku yang berhubungan dengan "prajurit Allah" serta penulis menggunakan metode eksegesis yang dapat dipahami sebagai cara sistematis untuk menafsirkan sebuah teks. Disini penulis juga menggunakan media elektronik sebagai bahan untuk menunjang penulisan ini.

\section{Hasil dan Pembahasan \\ Analisis Teks Efesus 6:10-20 \\ Kekuatan di Dalam Tuhan (Ayat 10)}

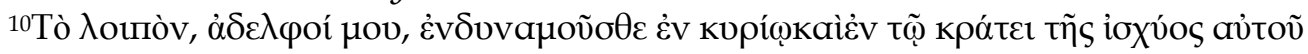

12 Alkitab Penuntun Hidup Berkelimpahan, (Malang: Gandum Mas, 2015)

${ }^{13}$ Merrill C. Tenney, Survei Perjanjian Baru (Jawa Timur: Gandum Mas, t.t.), 394-395.

14Tafsiran Alkitab Masa Kini 3: Matius-Wahyu (Jakarta: Yayasan Komunikasi Bina Kasih, 2006),

606.

15Warren Wiersbe, The Wiersbe Bible Commentary: New Testament (Italy: David C. Cook Communications Ministries, 2007), 622.

16 Gordon D. Fee dan Douglas Stuart, Hermeneutika Bagaimana Menafsirkan Alkitab Dengan Benar (Malang: Gandum Mas, 2000), 8. 
Frasa Tò 入ounòv(to loipon)disini berfungsi sebagai kata keterangan yang berjenis neuter dan ditujukan kepada orang pertama tunggal (singular). ${ }^{17}$ Ini adalah salah satu ciri khas Paulus dalam menulis surat-suratnya. Ketika ia akan mengakhiri sebuah surat,

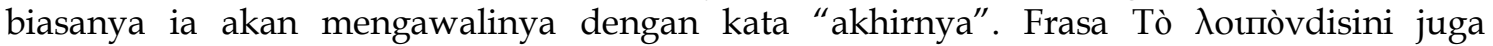
mungkin berarti "seperti apa yang telah kukatakan haruslah kamu terus melakukannya". ${ }^{18}$

Meskipun dalam Alkitab Terjemahan Baru frasa $\alpha \delta \varepsilon \lambda \varphi o i ́ ~ \mu o v(a d e l p h o i ~ m o u) ~ t i d a k$ diterjemahkan secara langsung, namun kata "kamu" dapat dikatakan merujuk kepada

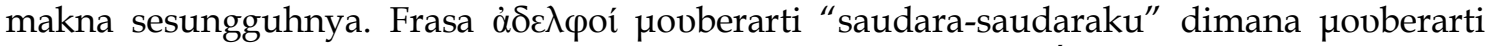
saya (kepunyaan) dan $\dot{\alpha} \delta \varepsilon \lambda \varphi o i ́ b e r a s a l ~ d a r i ~ k a t a ~ d a s a r ~ a \delta \varepsilon \lambda \varphi o ́ s(a d e l p h o s)$ yang bersifat maskulin dan memiliki arti "saudara". Namun makna saudara dalam konteks ini bukan secara langsung atau saudara yang berasal dari satu rahim tetapi Paulus mengungkapkannya secara figuratif. ${ }^{19}$

Frasa $\dot{\varepsilon}$ vovva menuliskan kuatkan dirimu di dalam Tuhan. Paulus mungkin mengambil ide ini dari 1 Samuel 30:6 dimana dikatakan, “...tetapi Daud menguatkan kepercayaannya kepada Tuhan,

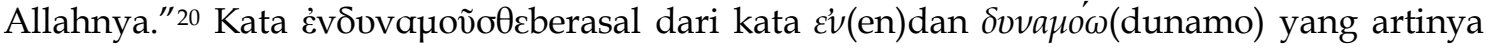
"membuat kuat; meningkatkan; memampukan". ${ }^{21}$ Kata ini digunakan dalam bentuk waktu sekarang (present)22, ditujukan kepada orang kedua jamak (second person plural), dan bersifat perintah pasif (imperative passive). ${ }^{23}$ Kata ini juga dapat berarti "dikuatkan" 24 yang dapat dikatakan bahwa ada Subjek yang memberikan kekuatan kepada objek. Sedangkan frasa $\dot{\varepsilon} v$ кupí (en kurio)menggambarkan kekuatan orang percaya, yang berarti kekuatan itu hanya dapat diperoleh melalui persekutuan dengan Kristus. ${ }^{25}$

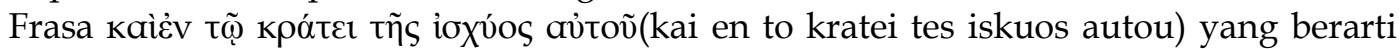
"dan di dalam kekuatan kuasa-Nya" tidak harus dikurangi maknanya menjadi "dalam kekuatanNya yang perkasa" tetapi lebih daripada itu bahwa frasa ini berarti "memiliki khasiat yang aktif dari kekuatan yang melekat dalam diriNya". ${ }^{26}$ Meskipun dalam bahasa aslinya terdapat kata kaìnamun pengurangan kata ini di dalam Alkitab Terjemahan baru tidak terlalu memiliki dampak yang besar terhadap ayat 10 ini.

${ }^{17}$ Wordstudy, e-sword-the sword of the Lord with an electronic edge, s.v. to loipon

${ }^{18}$ W. Robertson Nicoll, The Expositor's Greek Testament (Grand Rapids, Michigan: WM. B. Eerdmans Publishing Company, 1976), 381.

19 Wordstudy, e-sword-the sword of the Lord with an electronic edge, s.v. adelphos

${ }^{20}$ http:/ / www.blbclassic.org/commentaries/comm_view.cfm?AuthorID=2\&contentID=23923 $\&$ commInfo=217\&topic $=$ Ephesians (diakses 19 Maret 2019)

21 Wordstudy, e-sword-the sword of the Lord with an electronic edge, s.v. endunamousthe

22 Present bentuk kata kerja yang menandakan ajakan di mana dapat muncul salah satu nuansa sebagai berikut: a). nuansa meneruskan kegiatan yang telah dimulai, dan dalam larangan menghentikan kegiatan yang sedang dilakukan; b). nuansa untuk melakukan suatu kegiatan terus menerus atau berulang kali, dan dalam larangan untuk tidak pernah melakukan kegiatan itu. B. F. Drewes, Wilfrid Haubeck, dan Heinrich von Siebenthal, Kunci Bahasa Yunani Perjanjian Baru: Surat Roma Hingga Kitab Wahyu, 468.

${ }^{23}$ Nathan E. Han, A Parsing Guide To The Greek New Testament (Canada: Herald Press, Scottdale, Pa., 1971), 363.

24 Wordstudy, e-sword-the sword of the Lord with an electronic edge, s.v. endunamousthe, Jamieson-Fausset-and Brown Commentary

${ }^{25}$ W. Robertson Nicoll, The Expositor's Greek Testament (Grand Rapids, Michigan: WM. B. Eerdmans Publishing Company, 1976), 382.

26 Ibid. 


\section{Perjuangan melawan musuh (ayat 11-13)}

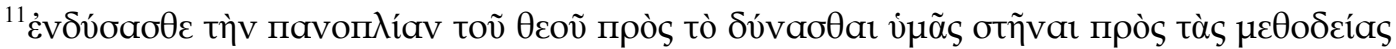

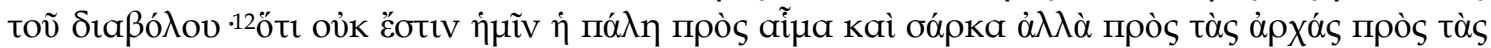

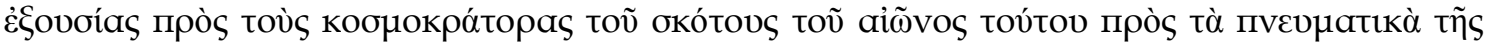

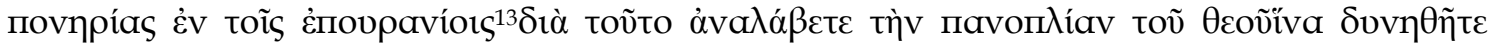

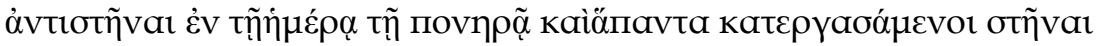

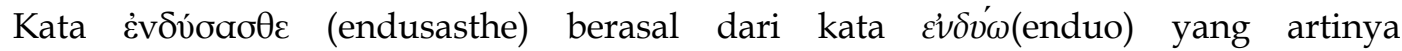
"mengenakan". ${ }^{27}$ Kata ini ditujukan kepada orang kedua jamak (second person plural), bersifat aorist pertama ${ }^{28}$, dan berbentuk perintah (imperative).

Selanjutnya terdapat kata паvоп $\lambda$ íav(panoplian)yang berarti "perlengkapan senjata". 30 Panoplia sendiri bukan hanya berarti senjata saja, tetapi seluruh perlengkapan senjata, yaitu perlengkapan lengkap tentara Romawi atau disebut "pria bersenjata" yang terdiri dari perisai, helm, penutup dada, pedang, dan tombak. ${ }^{31}$ Perlengkapan senjata ini disebutkan sebagai "perlengkapan senjata terang" (Roma 13:12) dan digunakan di sebelah kiri dan kanan (2 Kor 6:7) untuk menyerang dan untuk bertahan. ${ }^{32}$ Kata panoplia ini diikuti oleh frasa toṽ $\theta \varepsilon o$ (tou theou)yang bersifat genitif (menyatakan kepemilikan) yang berarti bahwa perlengkapan senjata ini datangnya dari Allah atau disediakan oleh Allah sendiri. Perlengkapan ini bukan karena hasil manusia tetapi semata-mata disediakan Allah lalu dikenakan oleh manusia.

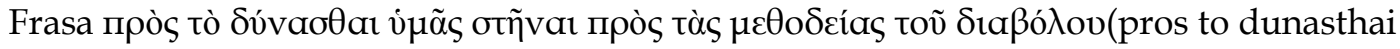
humas stenai pros tas methodeias tou diabolou) yang berarti "supaya kamu dapat bertahan melawan tipu muslihat Iblis" adalah pernyataan tentang objek yang menjadi alasan

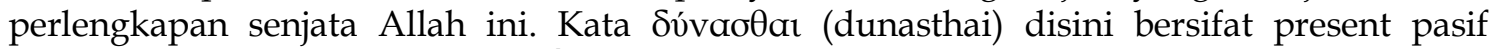

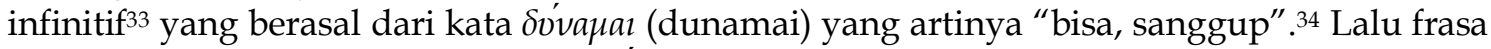

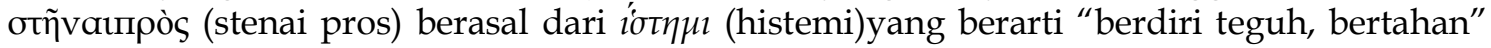
dan прòsadalah kata preposisi yang mempunyai arti "melawan". ${ }^{35}$ Frasa ini biasa digunakan oleh prajurit untuk mempertahankan dirinya dan sebagaioposisi dalam mengambil sikap

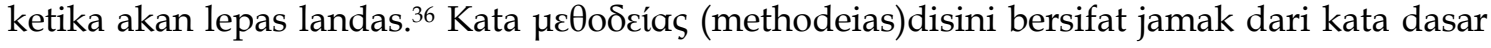

27 Wordstudy, e-sword-the sword of the Lord with an electronic edge, s.v. endusasthe

${ }^{28}$ Aorist pertama mengungkapkan sesuatu sebagai kegiatan atau situasi yang biasa, yang terjadi pada suatu ketika (terlepas apakah hal terus-menerus berlaku atau tidak). B. F. Drewes, Wilfrid Haubeck, dan Heinrich von Siebenthal, Kunci Bahasa Yunani Perjanjian Baru: Surat Roma Hingga Kitab Wahyu, 464.

29 Nathan E. Han, A Parsing Guide To The Greek New Testament (Canada: Herald Press, Scottdale, Pa., 1971), 363.

${ }^{30}$ Wordstudy, e-sword-the sword of the Lord with an electronic edge, s.v. panoplian

31 W. Robertson Nicoll, The Expositor's Greek Testament (Grand Rapids, Michigan: WM. B. Eerdmans Publishing Company, 1976), 382.

32 Wordstudy, e-sword-the sword of the Lord with an electronic edge, s.v. endunamousthe, Jamieson-Fausset-and Brown Commentary

33 Present pasif indikatif memiliki unsur makna terus menerus tidak senantiasa kuat. B. F. Drewes, Wilfrid Haubeck, dan Heinrich von Siebenthal, Kunci Bahasa Yunani Perjanjian Baru: Surat Roma Hingga Kitab Wahyu, 465.

${ }^{34}$ Wordstudy, e-sword-the sword of the Lord with an electronic edge, s.v. dunasthai

35 Wordstudy, e-sword-the sword of the Lord with an electronic edge, s.v. stenai

36 W. Robertson Nicoll, The Expositor's Greek Testament (Grand Rapids, Michigan: WM. B. Eerdmans Publishing Company, 1976), 382. 
$\mu \varepsilon \theta$ odsia. ${ }^{37}$ Metodeia dalam KBBI yang disebut metode berarti "cara teratur yang digunakan untuk melaksanakan suatu pekerjaan agar tercapai sesuai dengan yang dikehendaki" 38 yang dapat diartikan bahwa tipu muslihat disini adalah sebagai taktik yang dipakai oleh Iblis untuk melakukan pekerjaannya dengan tujuan untuk memperdaya orang percaya. Lalu kata

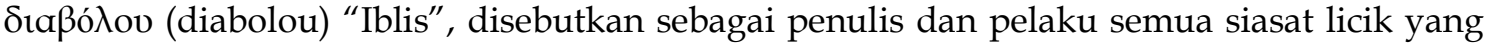
halus dan jahat. ${ }^{39}$

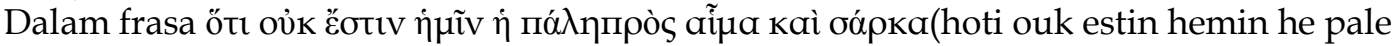

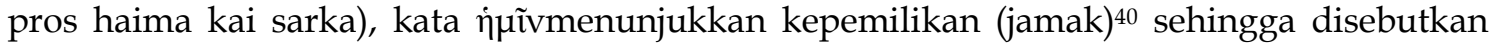
"perjuangan (milik) kita", dan kata חó $\eta \eta(p a l e) y a n g$ berarti "perjuangan" hanya sekali dipakai dalam Perjanjian Baru yang dalam pengertian umumnya ialah pertempuran tetapi biasa dalam konteks tertentu dapat diartikan sebagai pergulatan. ${ }^{41}$ "Gulat" disini menyiratkan bahwa itu adalah bentuk perlawanan menggunakan kaki dan tangan yang kosong dalam menyerang musuh. ${ }^{42}$ Lalu frasa aĩua kaì oópкa (haima kai sarka) hanya terjadi dalam ayat ini dan dalam Ibrani 2:14 tetapi memiliki arti yang sama yaitu sifat kemanusiaan yang lemah. ${ }^{43}$ Daging dan darah hanyalah alat setan belaka, karena musuh sesungguhnya ialah yang bersembunyi di balik itu semua yaitu setan itu sendiri. ${ }^{44}$

Frasa "tetapi melawan pemerintah-pemerintah, melawan penguasa-penguasa, melawan penghulu-penghulu dunia yang gelap ini, melawan roh-roh jahat di udara", menyebutkan ada 4 objek yang harus dilawan oleh orang-orang percaya. Kataờxós (arkhas)dari bentuk tunggal a'pX' (arkhe)berarti "pemerintah" 45 dan yang dimaksudkan bukanlah pemerintah dalam suatu negara tetapi pemerintahan Iblis"6. Lalu "penguasapenguasa" yang berasal dari kata ع'Sovoía (exousia)memiliki makna otoritas Iblis. ${ }^{47}$ Ada juga beberapa bagian lain dalam Alkitab yang menunjukkan tentang "pemerintah dan penguasa" ini (Roma 8:38; Efesus 1:20-21; Efesus 3:10-11; Kolose 2:15). Selanjutnya dikatakan "melawan penghulu-penghulu dunia yang gelap ini", yang berasal dari frasa прòs toùs кобнокра́тораৎ toṽ oKótous toṽ aĩ̃vostoútov(pros tous kosmokratoras tou skotous tou aionos toutou). Frasa ini tidak hanya berarti penghulu saja tetapi penghulu dunia yang memiliki kekuatan yang mendominasi dunia dan bekerja dimana-mana dalam kegelapan, ketidakpedulian, dan

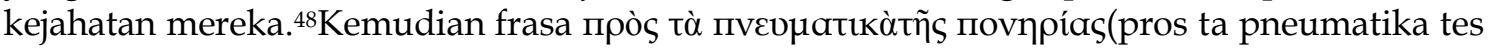
ponerias)memiliki arti "hal-hal rohani dari kejahatan; kejahatan yang sangat halus dan disublimasikan; kepalsuan terselubung dalam kebenaran" dan غ̇v toĩs غ̇novpavíors(en tois epouraniois) berarti "di stasiun yang paling mulia". Schoettgen berpendapat bahwa yang

37 Wordstudy, e-sword-the sword of the Lord with an electronic edge, s.v. methodeias

${ }^{38}$ https:// kbbi.web.id/metode (diakses 19 Maret 2019)

39 W. Robertson Nicoll, The Expositor's Greek Testament (Grand Rapids, Michigan: WM. B. Eerdmans Publishing Company, 1976), 382.

40 Wordstudy, e-sword-the sword of the Lord with an electronic edge, s.v. hemin

${ }^{41} \mathrm{~W}$. Robertson Nicoll, The Expositor's Greek Testament (Grand Rapids, Michigan: WM. B. Eerdmans Publishing Company, 1976), 383.

${ }^{42}$ Wordstudy, e-sword-the sword of the Lord with an electronic edge, s.v. pale, JamiesonFausset-and Brown Commentary

${ }^{43}$ W. Robertson Nicoll, The Expositor's Greek Testament (Grand Rapids, Michigan: WM. B. Eerdmans Publishing Company, 1976), 383.

44 Wordstudy, e-sword-the sword of the Lord with an electronic edge, s.v. sarx kai aima, Jamieson-Fausset-and Brown Commentary

45 Wordstudy, e-sword-the sword of the Lord with an electronic edge, s.v. arkas

${ }^{46} \mathrm{~W}$. Robertson Nicoll, The Expositor's Greek Testament (Grand Rapids, Michigan: WM. B. Eerdmans Publishing Company, 1976), 383.

47 Ibid.

48 Ibid. 
dimaksudkan disini ialah para rabi dan penguasa Yahudi. Hal ini menurutnya dibuktikan dengan frasa toṽ aĩõvostov́tov (dari dunia ini) yang sering digunakan untuk menunjuk Perjanjian Lama dan sistem Yahudi; dan frasa غ̇v toĩ غ̇noopavíorৎ (di tempat-tempat surgawi) yang sering digunakan untuk menandai waktu Perjanjian Baru dan dalam sistem Injil. ${ }^{49}$

Kata $\dot{\alpha} v \alpha \lambda \alpha ́ \beta \varepsilon \tau \varepsilon($ analabete) dalam ayat 13 yang berarti "ambillah"50 ditujukan kepada orang kedua jamak (second person plural) ${ }^{51}$ dan bersifat aorist kedua ${ }^{52}$ aktif

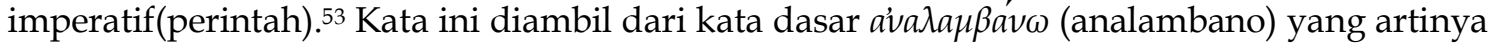
"mengangkat, mengambil". ${ }^{54}$ Lalu frasa "supaya kamu dapat mengadakan perlawanan"

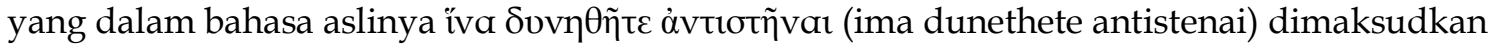
Paulus agar jemaat di Efesus tidak hanya berdiri teguh dalam kebebasan dimana Kristus telah membebaskan mereka, tetapi juga mengacaukan semua musuh rohani mereka, dan terus berada pada barisan untuk mempertahankan posisi melawan musuh dan selalu siap

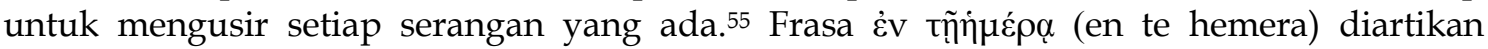
sebagai masa pencobaan yang bisa terjadi pada masa kini (Efesus 5:16) atau masa

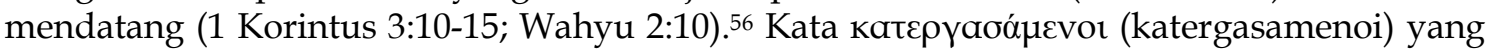
berarti "bekerja penuh; mencapai tujuan" dan kata orñva (stenai) "tetap berdiri"yang

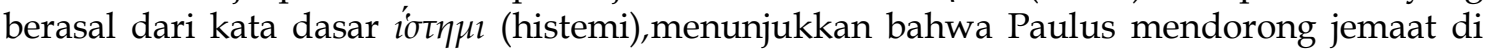
Efesus untuk tetap berdiri teguh tanpa ada satupun yang jatuh dalam menyelesaikan tugas pertempuran mereka melawan Iblis hingga mencapai tujuan akhir.

\section{Perlengkapan Senjata Allah (ayat 14-18)}

Berikatpinggangkan kebenaran dan berbajuzirahkan keadilan (ayat 14)

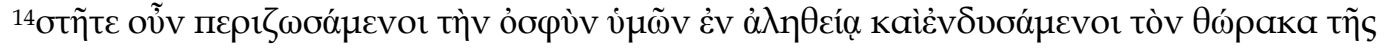

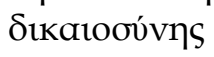

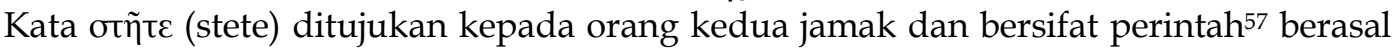
dari kata íø $\eta \mu$ yang berarti "berdiri" ${ }^{58}$ Frasa "berikatpinggangkan kebenaran" dalam

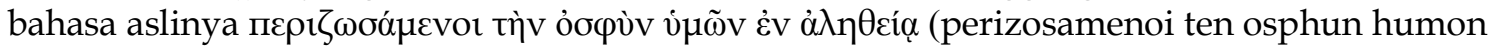
en aletheia). Sebenarnya, ikat pinggang bukanlah bagian dari perlengkapan senjata, tetapi sebelum baju zirah dapat terpasang seluruhnya, maka perlengkapan di bagian bawahnya

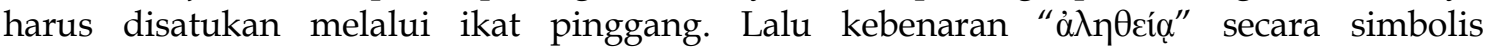

49 Wordstudy, e-sword-the sword of the Lord with an electronic edge, s.v. pros ta pneumatika tes ponerias en tois epouraniois, Adam Clarke's Commentary on the Bible

50 Wordstudy, e-sword-the sword of the Lord with an electronic edge, s.v. analabete

51 Nathan E. Han, A Parsing Guide To The Greek New Testament (Canada: Herald Press, Scottdale, Pa., 1971), 363.

52 Aorist kedua adalah permulaan dari peristiwa atau keadaan yang berkepanjangan, B. F. Drewes, Wilfrid Haubeck, dan Heinrich von Siebenthal, Kunci Bahasa Yunani Perjanjian Baru: Surat Roma Hingga Kitab Wahyu, 464.

53 Nathan E. Han, A Parsing Guide To The Greek New Testament (Canada: Herald Press, Scottdale, Pa., 1971), 363.

${ }^{54}$ B. F. Drewes, Wilfrid Haubeck, dan Heinrich von Siebenthal, Kunci Bahasa Yunani Perjanjian Baru: Surat Roma Hingga Kitab Wahyu (Jakarta: BPK Gunung Mulia, 2006), 465.

55 Wordstudy, e-sword-the sword of the Lord with an electronic edge, Adam Clarke's Commentary on the Bible

${ }^{56}$ Alkitab Edisi Studi, (Jakarta: LAI, 2013), 1924.

57 B. F. Drewes, Wilfrid Haubeck, dan Heinrich von Siebenthal, Kunci Bahasa Yunani Perjanjian Baru: Surat Roma Hingga Kitab Wahyu (Jakarta: BPK Gunung Mulia, 2006), 170.

58 Wordstudy, e-sword-the sword of the Lord with an electronic edge, s.v. histemi 
direpresentasikan sebagai sabuk yang melindungi perut sehingga dapat bertarung secara efektif. ${ }^{59}$ Menurut Abineno, kebenaran ini bukanlah sifat manusia, bukan juga perbuatannya, tetapi kebenaran Allah (bnd Efesus 4:21) kebenaran yang menyatakan diriNya dalam Berita Injil (Efesus 1:13), yang diterima oleh manusia dan yang menjadi kuasa yang memimpin hidupnya. ${ }^{60}$ Layaknya seorang prajurit, sebuah ikat pinggang akan dilepas ketika ia duduk, tetapi ketika ia siap untuk berperang maka ikat pinggang itu harus ia kenakan untuk mengeratkan seluruh perlengkapan yang ada di tubuhnya. Hal yang serupa juga dikatakan Yesus di dalam Lukas 12:35-36 dimana Yesus berkata, "Hendaklah pinggangmu tetap berikat dan pelitamu tetap menyala. Dan hendaklah kamu sama seperti orang-orang yang menanti-nantikan tuannya yang pulang dari perkawinan, supaya jika ia datang dan mengetok pintu, segera dibuka pintu baginya." 61

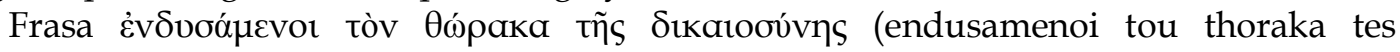
dikaiosunes) yang artinya "memakai penutup dada keadilan". 62 Peraturan yang berlaku dalam pemakaian baju zirah ini ialah, baju zirah tembaga digunakan kepada para pemimpin, dan baju zirah kulit digunakan kepada para prajurit. Dalam Perjanjian Lama ada begitu banyak contoh mengenai baju zirah ini. Tetapi istilah Paulus mengenai 'baju zirah keadilan' dalam ayat ini berasal dari Yesaya 59:17, dimana dalam Yesaya digunakan kata syiryonyang berarti suatu baju zirah yang melindungi bukan hanya dada saja tetapi juga punggung. ${ }^{63}$ Ketika prajurit memakai baju zirah ini untuk menutupi dada serta punggungnya, maka itu dapat membuatnya aman dari luka yang mematikan. Lalu kata

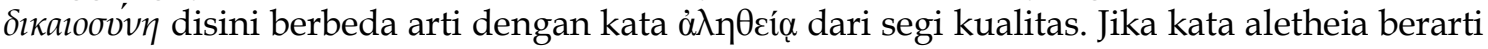
'kualitas kebenaran' maka kata dikaiosune artinya 'kualitas kejujuran moral'. ${ }^{64}$

Berkasutkan kerelaan (ayat 15)

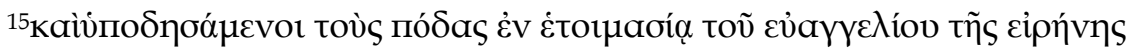

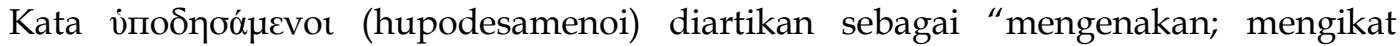

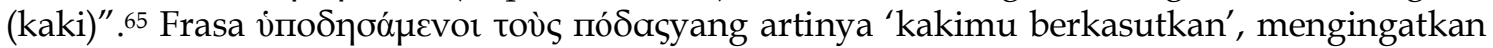
kita akan Yesaya 52:7 (NKJV) yang berbunyi, "How beautiful upon the mountains are the feet of him who brings good news, who proclaims peace, who brings glad tidings of good things, who

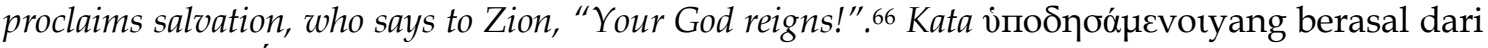

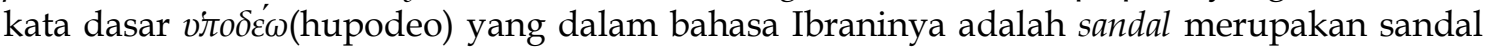
militer yang melindungi kaki prajurit dan memungkinkan dia bergerak dengan langkah yang cepat dan pasti. ${ }^{67}$ Dalam bahasa Yunani klasik, kata-benda étoupaóía (hetoimasia) tidak dikenal. Sebaliknya dalam Septuaginta (LXX), kata itu sering kita temui dengan arti: yang-

59 Wordstudy, e-sword-the sword of the Lord with an electronic edge, David Guzik's Enduring Word Commentary

60J. L. Ch. Abineno, Tafsiran Alkitab: Surat Efesus, 243.

${ }^{61}$ Alkitab TB, (Jakarta: LAI, 2011).

${ }^{62}$ Wordstudy, e-sword-the sword of the Lord with an electronic edge, s.v. endusamenoi ton toraka dikaiosunes

${ }^{63}$ Ensiklopedia Alkitab Masa Kini Jilid 1 A-L, s.v. baju zirah

${ }^{64} \mathrm{~W}$. Robertson Nicoll, The Expositor's Greek Testament (Grand Rapids, Michigan: WM. B. Eerdmans Publishing Company, 1976), 386.

65 Wordstudy, e-sword-the sword of the Lord with an electronic edge, s.v. upodesamenoi

${ }^{66}$ Holy Bible New King James Version, (Jakarta: LAI, 2012).

${ }^{67} \mathrm{~W}$. Robertson Nicoll, The Expositor's Greek Testament (Grand Rapids, Michigan: WM. B. Eerdmans Publishing Company, 1976), 386. 
teguh, yang-kokoh (bnd. Mzm 89:15; Zak 5:11; Ezr 2:68; 3:3; Yoh 43:11).68 Kata

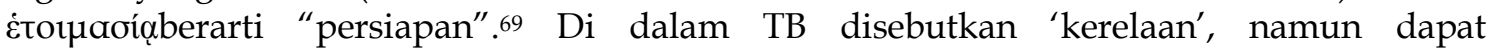
disimpulkan bahwa Paulus ingin jemaat di Efesus untuk selalu bersiap diri (secara rela) memberitakan Injil itu tidak peduli bagaimanapun situasi dan kondisinya.Meskipun tidak mudah, tetapi harus diingat bahwa kerelaan ini sama seperti kebenaran dan keadilan yang disebutkan Paulus sebelumnya, bahwa itu bukanlah hasil usaha atau pekerjaan dari jemaat di Efesus, tetapi kerelaan itu semata-mata adalah pemberian Allah. ${ }^{70}$

Pergunakanlah perisai iman (ayat 16)

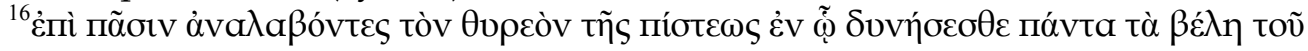

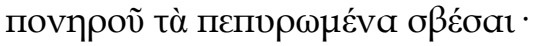

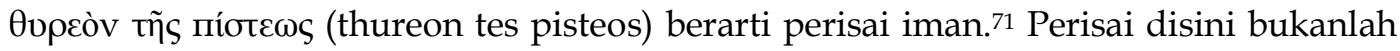
perisai kecil melainkan perisai besar yang menutupi seluruh tubuh pembawanya, bentuknya lonjong atau persegi empat panjang seperti pintu. ${ }^{72}$ Jika dilihat dari bentuknya, maka fungsi dari perisai ini untuk melindungi prajurit dari segala sesuatu yang dipanahkan musuh ke arah mereka. Lalu dikatakan perisai iman, karena iman adalah prasyarat dari kebenaran, keadilan dan kerelaan sebagai cara dari hidup atau eksistensi Kristen.73Iman kekristenan harus dibuktikan dalam kehidupan sehari-hari, kehidupan yang nyata yang dapat dilihat oleh orang lain, bahwa iman Kristen adalah iman yang hidup, bukan iman yang mati. ${ }^{74}$ Sekali lagi, bahwa iman disini bukanlah karena hasil dari usaha manusia tetapi iman yang diberikan oleh Allah sehingga hanya iman saja, di dalam Kristus, yang mampu menahan dan memadamkan semua senjata yang dipakai oleh Iblis untuk menyerang. ${ }^{75}$

Terimalah ketopong keselamatan dan pedang roh (ayat 17)

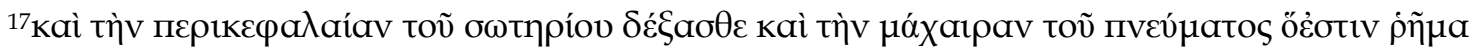
$\theta \varepsilon o \tilde{v}$

Pada zaman purba, ternyata pemakaian ketopong hanya terbatas untuk raja-raja dan pemimpin terkemuka saja. Ketopong ini pun ada yang terbuat dari kulit (2 Tawarikh 26:14) dan dari tembaga (1 Samuel 17:38). Tetapi di kalangan orang Romawi dan Yunani pada zaman Herodes, ketopong dari kedua bahan tersebut dipakai. Dan dalam ayat ini Paulus memberikan kiasan bahwa prajurit Kristen harus menggunakan ketopong. ${ }^{76}$ Kata ketopong

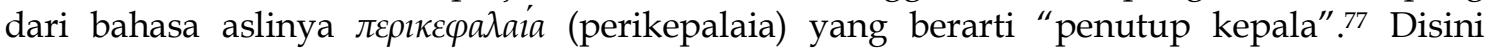
ditekankan lagi bahwa 'terimalah' yang menunjukkan adanya satu oknum yang memberikan ketopong maupun pedang itu, dan Oknum itu adalah Allah sendiri yang

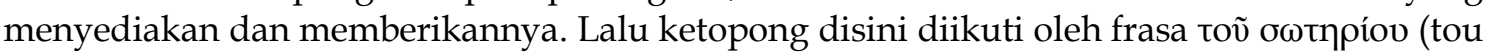

${ }^{68}$ J. L. Ch. Abineno, Tafsiran Alkitab: Surat Efesus, 244.

${ }^{69}$ Wordstudy, e-sword-the sword of the Lord with an electronic edge, s.v. etoimasia

70J. L. Ch. Abineno, Tafsiran Alkitab: Surat Efesus, 244.

${ }^{71}$ Wordstudy, e-sword-the sword of the Lord with an electronic edge, s.v. thureon tes pisteos

${ }^{72}$ Ensiklopedia Alkitab Masa Kini Jilid 1 A-L, s.v. perisai

73J. L. Ch. Abineno, Tafsiran Alkitab: Surat Efesus, 245.

${ }^{74}$ Riniwati, "Iman Kristen Dalam Pergaulan Lintas Agama," Jurnal Simpson 1, no. 1 (Juli 2014):

27-28.

75 Ibid.

${ }^{76}$ Ensiklopedia Alkitab Masa Kini Jilid 1 A-L, s.v. ketopong

77 Wordstudy, e-sword-the sword of the Lord with an electronic edge, s.v. perikepalaia 
soteriou) dimana toṽ memiliki arti genitif (kepemilikan) yang berarti "ketopong (yang adalah) keselamatan" ${ }^{78}$ Namun, keselamatan disini bukanlah keselamatan yang diharapkan saja tetapi keselamatan yang telah diberikan dalam Berita Injil sehingga orang yang mendengar dan menerimanya telah mendapat bagian di dalamnya. ${ }^{79}$ Dengan kata lain prajurit yang memakai ketopong tersebut sudah mendapatkan bagian dalam keselamatan itu.

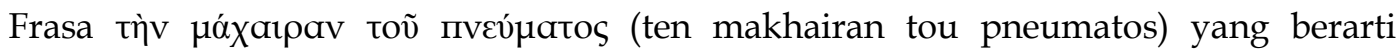
pedang Roh diikuti dengan frasa $\dot{\rho} \tilde{\eta} \mu \alpha$ $\theta \varepsilon o \tilde{v}($ hemera theou)yang berarti Firman Allah, memiliki arti bahwa pedang Roh ini disediakan oleh Roh Allah sendiri. ${ }^{80}$ Jika membaca tentang pedang Roh dan Firman Allah maka pikiran kita akan dibawa kepada Ibrani 4:12 dimana berbunyi, "Sebab Firman Allah hidup dan kuat dan lebih tajam daripada pedang bermata dua mana pun; ia menusuk amat dalam sampai memisahkan jiwa dan roh, sendisendi dan sumsum; ia sanggup membedakan pertimbangan dan pikiran hati kita." 81 Menurut Calvin, relevansi dan otoritas Alkitab baru nyata di antara orang Kristen apabila mereka menganggap bahwa hanya di dalam Alkitab mereka dapat mendengar firman yang hidup. ${ }^{82}$ Dalam Firman Allah, Roh bekerja seperti pedang dan oleh "pedang Roh" ini yaitu firman yang di dalamnya Roh bekerja, semua kuasa-kuasa gelap ditelanjangi dari kuasa mereka yang semu, sehingga nampak dengan jelas bahwa satu-satunya kuasa yang benar ialah kuasa Allah. ${ }^{83}$

\section{Kuasa Doa (ayat 18-20)}

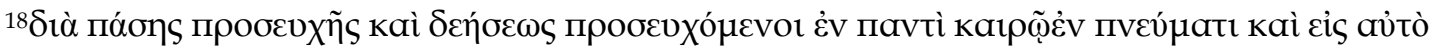

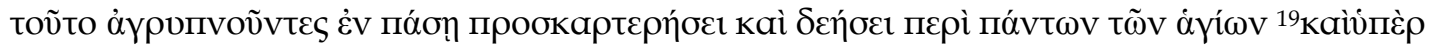

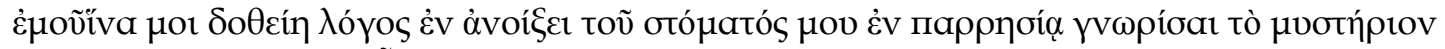

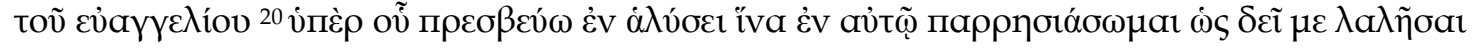

Kata doa dalam ayat 18-20 ini diulang sebanyak 4 kali sehingga dapat dikatakan bahwa selain perlengkapan senjata yang dibutuhkan, doa adalah suatu hal yang sangat penting untuk jemaat dalam melawan musuh mereka yaitu Iblis. Paulus menasihatkan jemaat di Efesus agar mereka senantiasa berdoa. Untuk dapat menjalankan perjuangan mereka melawan kuasa-kuasa gelap di udara, anggota-anggota jemaat bukan saja membutuhkan firman Allah, tetapi juga doa yang diucapkan setiap waktu atau terus-

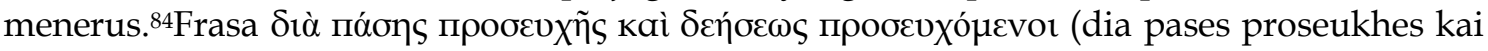
deseos proseukhomenoi) yang berarti "dalam segala doa dan permohonan" 85 menunjukkan bahwa syarat terbesar agar dapat menghadapi pertempuran dengan baik adalah dengan

${ }^{78}$ W. Robertson Nicoll, The Expositor's Greek Testament (Grand Rapids, Michigan: WM. B. Eerdmans Publishing Company, 1976), 388.

79J. L. Ch. Abineno, Tafsiran Alkitab: Surat Efesus, 247.

80 W. Robertson Nicoll, The Expositor's Greek Testament (Grand Rapids, Michigan: WM. B. Eerdmans Publishing Company, 1976), 388.

${ }^{81}$ Alkitab TB, (Jakarta: LAI, 2011).

82 Daniel L. Lukito, “490 Tahun Reformasi: Apakah Sola Scriptura Masih Secara Konsisten Menjadi Pegangan Gereja-Gereja Reformed Masa Kini?,” Jurnal Veritas 8, no. 2 (Oktober 2007), 163.

83J. L. Ch. Abineno, Tafsiran Alkitab: Surat Efesus, 248.

${ }^{84} \mathrm{Ibid}, 249$.

85 Wordstudy, e-sword-the sword of the Lord with an electronic edge, s.v. dia pases proseukes kai deseos proseukomenoi 
berdoa. ${ }^{86}$ Doa merupakan sarana di mana kita dapat memerintah bersama-Nya di bumi (2 Tim 2:12; Why 5:10; 20:6). Doa memberdayakan kita untuk dapat memenuhi panggilan kita menjadi rekan sepemerintahan dengan Allah. ${ }^{87}$ Frasa di dalam Roh atau dalam bahasa aslinya $\dot{\varepsilon} \mathrm{V}$ กvev́patı(en pneumati) ${ }^{88}$ bukan berarti berdoa menggunakan bahasa Roh atau berdoa dengan Roh tetapi yang Paulus maksudkan ialah berdoa sebagai pekerjaan Roh sehingga nyata dari nasihat Paulus kepada jemaat di Efesus agar mereka, "berjaga-jaga di dalam doa mereka dengan permohonan yang tak putus-putusnya." ${ }^{89}$ Lalu $\dot{\alpha} \gamma i ́ \omega v$ (hagion) yang berarti "orang-orang Kudus" 90 memiliki arti tidak hanya jemaat di Efesus saja tetapi juga jemaat yang ada di tempat lain karena doa adalah "tali" yang menghubungkan mereka satu sama lain untuk bersama-sama dengan Tuhan mereka. ${ }^{91}$

Dalam ayat 19-20a, Paulus tidak hanya menginginkan jemaat agar mendoakan anggota jemaat yang lain, tetapi juga Paulus ingin agar jemaat mendoakannya. Dapat dilihat bahwa dukungan doa dari jemaat sangat dibutuhkan oleh Paulus agar ketika “...ia membuka mulutnya, dikaruniakan perkataan yang benar, sehingga ia dengan keberanian memberitakan rahasia Injil yang ia layani sebagai utusan yang dipenjarakan." Disini Paulus meminta dua hal di dalam permohonan doanya, yaitu dikaruniakan perkataan yang benar dan diberikan keberanian memberitakan Injil. Frasa 'perkataan yang benar' dalam bahasa aslinya yaitu $\lambda$ órosberarti 'firman, ucapan' 92 sehingga Paulus mau mengatakan bahwa yang harus ia beritakan adalah firman Allah itu sendiri dan ia hanya dapat memberitakannya jika Tuhan membuka mulutnya. ${ }^{93}$ Lalu permohonan doa Paulus yang kedua ialah agar ia diberikan keberanian dalam memberitakan rahasia Injil sebagai utusan yang dipenjarakan. Adam Clarke mengatakan bahwa rahasia Injil ini adalah seluruh doktrin mengenai Kristus dimana belum sepenuhnya diungkapkan pada waktu itu. ${ }^{94}$ Karena rahasia Injil ini juga yang membuat Paulus saat itu berada dalam penjara. Paulus ingin agar meskipun karena Injil dia dipenjara namun biarlah itu tidak mengurangi keberaniannya dalam memberitakan Injil. Sehingga ia memohon doa kepada jemaat agar ia diberikan keyakinan yang tidak mengenal takut dalam memberitakan Injil. ${ }^{95}$ Lalu Paulus mengulang lagi permohonannya dalam ayat 20b, "Berdoalah supaya dengan keberanian aku menyatakannya, sebagaimana seharusnya aku berbicara". Disini dapat dilihat bagaimana Paulus sangat mengharapkan dukungan doa dari jemaat di Efesus dalam memberitakan Injil sampai ia mengulang kembali perkataannya dalam ayat ini yang telah ia ungkapkan di ayat sebelumnya. Abineno mengatakan, "oleh doa jemaat pemberita-pemberita Injil bukan saja terpelihara dari ketakutan, tetapi juga dari kecongkakan dan keberanian yang berlebih-lebihan. Dengan jalan demikian, mereka dapat menunaikan tugas mereka sesuai dengan kehendak/hukum Allah." 96

${ }^{86}$ W. Robertson Nicoll, The Expositor's Greek Testament (Grand Rapids, Michigan: WM. B. Eerdmans Publishing Company, 1976), 389.

87 Soerono, "Doa Peperangan Rohani Tingkat Strategis dan Biblical Warfare Worldview: Kawan atau Lawan?," Jurnal Veritas 9, no.1 (April 2008): 22.

88 Wordstudy, e-sword-the sword of the Lord with an electronic edge, s.v. en pneumati

89 J. L. Ch. Abineno, Tafsiran Alkitab: Surat Efesus, 249.

${ }^{90}$ Wordstudy, e-sword-the sword of the Lord with an electronic edge, s.v. hagion

91 J. L. Ch. Abineno, Tafsiran Alkitab: Surat Efesus, 250.

92 Wordstudy, e-sword-the sword of the Lord with an electronic edge, s.v. logos

93 J. L. Ch. Abineno, Tafsiran Alkitab: Surat Efesus, 252.

94 Wordstudy, e-sword-the sword of the Lord with an electronic edge, Adam Clarke's Commentary on the Bible

95 W. Robertson Nicoll, The Expositor's Greek Testament, 391.

96 J. L. Ch. Abineno, Tafsiran Alkitab: Surat Efesus, 254. 


\section{Implikasi \\ Implementasi Prajurit Allah Dalam Kehidupan Orang Percaya \\ Mengandalkan Kekuatan Allah}

Sebelum Paulus memberikan instruksi agar mengenakan perlengkapan senjata Allah, ia memberikan dorongan kepada jemaat di Efesus agar senantiasa kuat di dalam Tuhan, di dalam kekuatan kuasa-Nya.Kekuatan Allah dan kuasa Allah adalah hal yang paling pertama dan utama yang harus dikenakan dalam kehidupan orang percaya sebelum maju berperang melawan musuh menggunakan perlengkapan senjata yang ada. Daud dalam perkelahiannya dengan Goliat sebelum ia maju, ia berkata, "Engkau mendatangi aku dengan pedang dan tombak dan lembing, tetapi aku mendatangi engkau dengan nama TUHAN semesta alam, Allah segala barisan Israel yang kautantang itu." (1 Samuel 17:45). Memang Daud tidak mengungkapkan secara langsung kekuatan dan kuasa Allah, tetapi melalui frasa 'TUHAN semesta alam', dapat menunjukkan bagaimana kekuasaan dan kekuatan Allah itu. Begitu juga dengan Musa, ketika ia memperingati bangsa Israel jika mereka akan memasuki medan peperangan, ia berkata, "Apabila kamu menghadapi pertempuran, maka seorang imam harus tampil ke depan dan berbicara kepada rakyat, dengan berkata kepada mereka: Dengarlah, hai orang Israel! Kamu sekarang menghadapi pertempuran melawan musuhmu; janganlah lemah hatimu, janganlah takut, janganlah gentar dan janganlah gemetar karena mereka, sebab TUHAN, Allahmu, Dialah yang berjalan menyertai kamu untuk berperang bagimu melawan musuhmu, dengan maksud memberikan kemenangan kepadamu" (Ulangan 20:24). Baik Daud maupun Musa, mereka menyadari bahwa ketika mereka turun dalam medan peperangan, kekuatan dan kuasa Allah lah yang harus mereka andalkan terlebih dahulu. Begitu pula dengan orang percaya, sebelum menggunakan perlengkapan senjata yang disediakan, orang percaya harus mengandalkan terlebih dahulu kekuatan Allah di dalam dirinya dan menaruh penuh dirinya ke dalam tangan kuasa Allah.

\section{Memiliki kewaspadaan setiap saat}

Seorang prajurit harus senantiasa berjaga-jaga dan memiliki tingkat kewaspadaan yang tinggi sebelum musuh maju menyerang. Paulus sangat menekankan jemaat di Efesus bahwa ketika mereka telah mengenakan perlengkapan senjata Allah, mereka juga harus selalu berjaga-jaga karena perlawanan mereka bukan dengan musuh yang biasa-biasa saja tetapi perlawanan mereka adalah perlawanan terhadap Iblis yang merupakan penguasa dunia gelap.Iblis adalah panglima tertinggi dari semua setan, ia mengutus roh-roh jahat ini kepada manusia untuk membawa bayangan kegelapan atas roh manusia. ${ }^{97}$ Harus selalu diingat bahwa Iblis maupun roh-roh jahat itu bukan sebuah benda. Mereka adalah makhlukmakhluk yang berakal jahat, dan masing-masing ingin menyatakan dirinya melalui suatu tubuh.98Seorang prajurit harus selalu memiliki kewaspadaan karena ketika seorang prajurit lupa bahwa dia sedang dalam masa peperangan, maka ia pasti akan jatuh. Di dalam dunia peperangan, seorang prajurit juga harus selalu berhati-hati terhadap "Sindrom Taman Getsemani", dimana ia harus waspada terhadap godaan untuk jatuh tertidur ketika ia seharusnya berjaga-jaga. ${ }^{99}$

\section{Berjaga-jaga di dalam doa}

Doa memiliki kuasa yang sangat besar dan sangat penting bagi kerohanian orang percaya. Orang percaya yang dalam masa peperangan rohani hendaknya senantiasa berjaga-

\footnotetext{
${ }^{97}$ H.A. Maxwell Whyte, Roh Jahat dan Pelayanan Pelepasan (Malang: Gandum Mas, 2002), 89.

98 Ibid, 56.

99 Daud Tony, Dunia Peperangan Rohani (Jakarta: Betlehem, 2010), 63.
} 
jaga di dalam doa sebagaimana Paulus menasihati jemaat di Efesus. Dapat dikatakan bahwa hanya melalui doa, kekuatan rohani dan perlengkapan senjata itu dapat bekerja. Secara teori, orang Kristen yang tidak berdoa dapat menjadi kuat dan mengenakan perlengkapan senjatanya tetapi ia tidak dapat maju berperang. ${ }^{100}$ Belajar dari teladan Yesus ketika Ia dicobai oleh Iblis (Matius 4:1-11), dapat dilihat bahwa ketika Iblis mencobai Dia, maka Yesus melawannya menggunakan pedang roh, yaitu firman Allah sendiri. Namun sebelumnya itu, ia berpuasa empat puluh hari empat puluh malam. Memang tidak dijelaskan secara rinci apa saja yang dilakukan Yesus selama empat puluh hari empat puluh malam itu, tetapi dapat dipastikan bahwa selama itu juga Yesus berjaga-jaga di dalam doaNya sehingga ketika Ia dicobai Iblis, Ia mampu mengalahkannya. Seorang prajurit yang berdoa, hendaklah ia berdoa di dalam nama Yesus. Yohanes 14:13-14 dengan jelas mengatakan, “dan apa juga yang kamu minta dalam nama-Ku, Aku akan melakukannya, supaya Bapa dipermuliakan di dalam Anak. Jika kamu meminta sesuatu kepada-Ku dalam nama-Ku, Aku akan melakukannya." Tidak berarti bahwa berdoa di dalam nama Yesus seperti sebuah "mantra" agar doa dikabulkan. Tetapi berdoa di dalam nama Yesus berarti berserah sepenuhnya di dalam Dia dan berdoa dengan otoritas Yesus. Seperti yang tertulis sebelumnya, bahwa seorang prajurit hendaknya mengandalkan kekuatan dan kuasa Allah, maka disini juga dapat dilihat bahwa seorang prajurit harus tunduk sepenuhnya kepada kehendak Allah. Ketika orang percaya berdoa, maka haruslah kehendak Allah yang diutamakan. Sama seperti Yesus yang ketika berdoa di Taman Getsemani, Ia berkata, "janganlah seperti yang Kukehendaki, melainkan seperti yang Engkau kehendaki" (Matius 26:39). Begitu pula ketika Yesus mengajarkan hal berdoa kepada murid-muridNya, di dalam doa itu ada berbunyi “...jadilah kehendakMu..." (Matius 6:10). Maka, dalam peperangan orang percaya melawan musuh-musuh hendaklah ia senantiasa berjaga-jaga di dalam doanya dengan penuh penyerahan kepada Allah.

\section{Rekomendasi Untuk Penelitian Lanjutan}

Orang Kristen adalah prajurit Kristus yang seharusnya siap berperang.Sebagai seorang prajurit, tentunya harus melatih dan mempelajari teknik dalam berperang, serta melengkapidiridengansenjatayang ada.Penelitian dalam penulisan ini hanya berfokus kepada orang percaya sebagai prajuritKristusdansenjata yang dimilikinya. Sehingga, adapun rekomendasi terhadap analisa dalam penulisan ini untuk penelitian selanjutnya adalah sebagai berikut:

1. Dalam penelitian selanjutnya dapat dicantumkan bagaimana prajurit Allah mengenali medan pertempuran yang dihadapi. Untuk zaman ini, medan pertempuran orang percaya ialah melawan postmodernisme. Postmodernisme sendiri mengajarkan bahwa tidak ada kebenaran yang mutlak terutama dalam hal agama dan spiritualitas. Namun, Yesus sendiri yang berkata bahwa Ia lahir dan untuk itulah Ia datang kedalam dunia ini, supaya Ia member kesaksian tentang kebenaran (Yoh 18:37). Yesus juga berkata dengan pasti bahwa Ialah satu-satunya jalan, dan kebenaran, dan hidup (Yoh 14:6). Tentu ini menjadi pukulan terhadap penganut paham postmodernisme.

2. Penelitian selanjutnya juga dapat menganalisa lebih dalam siapakah musuh yang dihadapi. Pada awal mula penciptaan Allah yang telah berbicara bahwa, "Aku akan mengadakan permusuhan antara engkau dan perempuan ini, antara keturunanmu dan keturunannya" (Kej 3:15). Ini menunjukkan bahwa Allah sendiri yang menetapkan Iblis

100 Wordstudy, e-sword-the sword of the Lord with an electronic edge, David Guzik's Commentary 
menjadi musuh manusia seumurhidup. Alkitab dengan jelasberkata bahwa, "seluruh dunia berada di bawah kuasa sijahat" (1 Yoh 5:19) dan untuk itulah orang percaya perlu mengetahui siapa musuh mereka sehingga ia dapat sadar dan berjaga-jaga.

3. Membaca siasat musuh juga perlu dilakukan dalam sebuah pertempuran dan kemampuan ini haruslah dimiliki oleh seorang prajurit. Di dalam 2 Korintus 10:3-5 Paulus mengatakan, "memang kami masihhidup di dunia, tetapi kami tidak berjuang secara duniawi, karena senjata kami dalamperjuangan bukanlah senjata duniawi, melainkan senjata yang diperlengkapi dengan kuasa Allah, yang sanggup untuk meruntuhkan benteng-benteng. Kami mematahkan setiap siasat orang dan merubuhkan setiap kubu yang dibangun oleh keangkuhan manusia untuk menentang pengenalanakan Allah." Menurut Paulus ada benteng-benteng rohani di dalam dunia ini yang terdiri dari siasat dan keangkuhan manusia. Istilah siasat disini dalam bahasa aslinya berarti "ide, konsep, nalar, atau filsafat". Manusia membangun siasat untuk melindungi diri mereka dari kebenaran Allah. Sehingga sebagai orang percaya, kita dipanggil untuk menghancurkan benteng-benteng ini dan menyelamatkan orang-orang yang ada di dalamnya.

4. Lamanya waktu berperang juga dapat dianalisa dalam penelitian selanjutnya. Seperti yang dikemukakan penulis sebelumnya bahwa seorang prajurit haruslah selalu siap sedia dengan senjata yang ia miliki. Pengkhotbah 3:8 mengatakan, "ada waktu untuk mengasihi, ada waktu untuk membenci; ada waktu untuk perang, ada waktu untuk damai." Perang dalam kehidupan orang percaya tidak dapat terelakkan. Sehingga penelitian jangka waktu perang bagi orang percaya ini bertujuan agar mereka tidak membuang waktu hidupnya dengan sia-sia melainkan mempergunakan waktu yang ada sebaik mungkin, karena hari-hari ini adalah jahat (Efesus 5:16).

5. Seorang prajurit tentu memiliki komandan. Dalam penelitian berikutnya dapat dianalisa bagaimanaTuhan yang menjadi komandan dalam sebuah pertempuran. Tuhanlah yang menjadi komandan paraprajurit. Peperangan rohani adalah kehendak Tuhan. Tuhan sendiri yang memerintahkan orang percaya untuk mengangkat senjata dalam peperangan. Tuhan sendiri yang memberitakan bahwa kerajaan-Nyasudah datang, dan Dia juga yang memerintahkan orang percaya untuk memajukan kerajaan-Nya melalui pemberitaan Injil. Ketika Tuhan yang turun tangan dalam peperangan, maka tidak ada satupun yang dapatmelawan.

\section{Kesimpulan}

Berdasarkan hasil uraian penulis dalam karya ilmiah ini tentang konsep prajurit Allah berdasarkan Efesus 6:10-20 dan implementasinya dalam kehidupan orang percaya, maka penulis menarik beberapa kesimpulan sebagai berikut:

Pertama, perlengkapan senjata Allah wajib dikenakan oleh setiap orang percaya yang adalah prajurit Allah itu sendiri. Perlengkapan senjata ini perlu dikenakan setiap saat dikarenakan peperangan terjadi hampir setiap saat.

$K e d u a$, orang percaya akan mengalami peperangan rohani selama hidupnya sampai nanti ia masuk ke dalam hidup yang kekal. Orang percaya tidak akan terlepas dari yang namanya peperangan rohani selama hidupnya. Untuk itu ia perlu mengetahui bahwa hidupnya bukanlah sesuatu yang dihabiskan dengan kesia-siaan tetapi dengan kesiapsiagaan dalam menghadapi musuh seumur hidup yaitu Iblis.

Ketiga, seorang prajurit Allah harus senantiasa mengandalkan kekuatan yang datang dari Allah sendiri. Seorang prajurit tidak akan menang tanpa mengandalkan kekuatan Allah. Karena perlengkapan senjata datangnya dari Allah sendiri maka prajurit juga mengandalkan kekuatan yang datangnya dari Allah sendiri. Jika ia mengandalkan kekuatan manusiawinya 
maka dapat dipastikan ia akan jatuh dalam menghadapi musuh, dan kalah telak dalam pertempuran.

Keempat, orang percaya harus selalu memiliki kewaspadaan terhadap serangan musuh, yaitu Iblis yang bisa datang kapan saja. Iblis memiliki taktik yang jahat dalam peperangan. Jika orang percaya tidak memiliki kewaspadaan maka Iblis dapat dengan mudah menyerangnya sehingga ia dapat dikalahkan.

Kelima, penyerahan diri sepenuhnya melalui doa haruslah dilakukan oleh setiap prajurit Allah yang ada dalam masa peperangan rohani. Doa bagi orang percaya merupakan suatu keharusan dalam menghadapi peperangan. Tanpa penyerahan diri di dalam doa, kemungkinan besar prajurit tersebut tidak dapat menghadapi peperangan yang begitu besar.

Keenam, setiap orang percaya saat ini harus mengandalkan kekuatan Allah yang digumuli di dalam doa setiap saat sehingga ia dapat berjaga-jaga dalam kewaspadaan terhadap serangan Iblis dalam kehidupannya.

\section{Rujukan}

Alkitab

Alkitab Penuntun Hidup Berkelimpahan. Malang: Gandum Mas, 2015.

Alkitab Edisi Studi. Jakarta: Lembaga Alkitab Indonesia, 2013.

Alkitab Terjemahan Baru Bahasa Indonesia. Jakarta: Lembaga Alkitab Indonesia, 2011.

Holy Bible New King James Version. Jakarta: Lembaga Alkitab Indonesia, 2012.

\section{Ensiklopedi}

Ensiklopedi Alkitab Masa Kini Jilid I. Jakarta: Yayasan Komunikasi Bina Kasih/OMF, 1999.

Packer J.I., Tenney Merril C., dan Jr. William White. Ensiklopedia Fakta Alkitab: Bible Almanac 1. Jawa Timur: Gandum Mas, 2003.

Jurnal

Lukito, Daniel L. "490 Tahun Reformasi: Apakah Sola Scriptura Masih Secara Konsisten Menjadi Pegangan Gereja-Gereja Reformed Masa Kini?" Veritas, 2007: 151-168.

Mamahit, Ferry Y. "Christus Victor dan Kemenangan Orang Kristen Terhadap Kuasa Kegelapan." Veritas, 2004: 1-21.

Riniwati. "Iman Kristen Dalam Pergaulan Lintas Agama." Jurnal Simpson, 2014: 21-36.

Setiawan, Roby. "Tinjauan Terhadap Bidat Gnosticism dan 'Injil' Thomas." Jurnal Simpson, 2015: 1-10.

Soerono. "Doa Peperangan Rohani Tingkat Strategis dan Biblical Warfare Worldview: Kawan atau Lawan?" Veritas, 2008: 17-36.

Buku

Abineno, J.L. Ch. Tafsiran Alkitab: Surat Efesus. Jakarta: BPK Gunung Mulia, 2009.

Drewes B.F., Haubeck Wilfrid, dan Siebenthal von Heinrich. Kunci Bahasa Yunani Perjanjian Baru: Surat Roma Hingga Kitab Wahyu. Jakarta: BPK Gunung Mulia, 2006.

Fee, Gordon D., and Douglas Stuart. Hermeneutika Bagaimana Menafsirkan Alkitab Dengan Benar. Malang: Gandum Mas, 2000.

Halley, Henry H. Penuntun ke Dalam Perjanjian Baru. Surabaya: Yakin, t.t.

Hakh, Samuel Benyamin. Perjanjian Baru: Sejarah, Pengantar, dan Pokok-pokok Teologisnya. Bandung: Bina Media Informasi, 2010. 
Han, Nathan E. A Parsing Guide To The Greek New Testament. Canada: Herald Press, Scottdale, 1971.

Nicoll, W. Robertson. The Expositor's Greek Testament. Grand Rapids, Michigan: WM. B. Eerdmans Publishing Company, 1976.

Tafsiran Alkitab Masa Kini 3: Matius-Wahyu. Jakarta: Yayasan Komunikasi Bina Kasih, 2006.

Tenney, Merril C. Survei Perjanjian Baru. Jawa Timur: Gandum Mas, t.t.

Tony, Daud. Dunia Peperangan Rohani. Jakarta: Betlehem, 2010.

Wiersbe, Warren. The Wiersbe Bible Commentary: New Testament. Italy: David C. Cook Communications Ministries, 2007.

Whyte, H.A. Maxwell. Roh Jahat E Pelayanan Pelepasan. Malang: Gandum Mas, 2002.

Internet

Blue Letter Bible, http://www.blbclassic.org/lang/lexicon/Lexicon.cfm?strongs=G3833 (diakses 15 Maret 2019).

The Armor of God An Exposition of Ephesians, https:// dandelionsalad.wordpress.com/2007/09/02/the-armor-of-god-an-expositionof-ephesians-610-17-by-warren-doud/ (diakses 18 Maret 2019)

Commentaries of Ephesians, https://biblehub.com/commentaries/ephesians/6-11.htm (diakses 18 Maret 2019)

Tripp, Paul David., Situs Online Teologi Reformed Injili, http://reformed.sabda.org/firman_menjadi_daging_1 (diakses 20 Maret 2019)

Blue Letter Bible,

http://www.blbclassic.org/commentaries/comm_view.cfm?AuthorID=2\&contentID= 23923\&commInfo=217\&topic $=$ Ephesians (diakses 19 Maret 2019)

KBBI, https:// kbbi.web.id/metode (diakses 19 Maret 2019)

Wordstudy, e-sword. 